\title{
Long-Term Results: New Construction Occupied Test House, Urbana, Illinois
}

D. Stecher and K. Allison IBACOS, Inc.

October 2012 


\section{NOTICE}

This report was prepared as an account of work sponsored by an agency of the United States government. Neither the United States government nor any agency thereof, nor any of their employees, subcontractors, or affiliated partners makes any warranty, express or implied, or assumes any legal liability or responsibility for the accuracy, completeness, or usefulness of any information, apparatus, product, or process disclosed, or represents that its use would not infringe privately owned rights. Reference herein to any specific commercial product, process, or service by trade name, trademark, manufacturer, or otherwise does not necessarily constitute or imply its endorsement, recommendation, or favoring by the United States government or any agency thereof. The views and opinions of authors expressed herein do not necessarily state or reflect those of the United States government or any agency thereof.

Available electronically at http://www.osti.gov/bridge

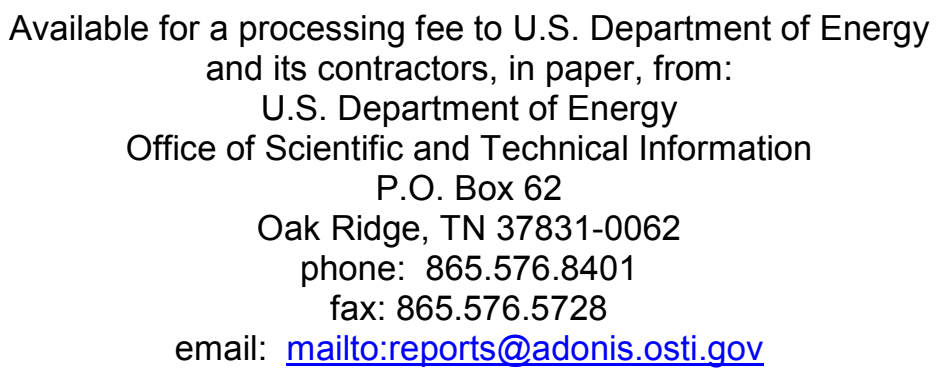

Available for sale to the public, in paper, from:

U.S. Department of Commerce

National Technical Information Service

5285 Port Royal Road

Springfield, VA 22161

phone: 800.553 .6847

fax: 703.605.6900

email: orders@ntis.fedworld.gov

online ordering: http://www.ntis.gov/ordering.htm

\footnotetext{
Printed on paper containing at least $50 \%$ wastepaper, including $20 \%$ postconsumer waste
} 


\title{
Long-Term Results: New Construction Occupied Test House, Urbana, Illinois
}

\author{
Prepared for: \\ The National Renewable Energy Laboratory \\ On behalf of the U.S. Department of Energy's Building America Program \\ Office of Energy Efficiency and Renewable Energy \\ 15013 Denver West Parkway \\ Golden, CO 80401 \\ NREL Contract No. DE-AC36-08GO28308 \\ Prepared by: \\ D. Stecher and K. Allison \\ IBACOS, Inc. \\ 2214 Liberty Avenue \\ Pittsburgh, Pennsylvania 15222 \\ NREL Technical Monitor: Michael Gestwick \\ Prepared under Subcontract No. KNDJ-0-40341-02
}

October 2012 
[This page left blank] 


\section{Contents}

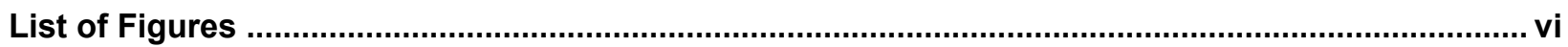

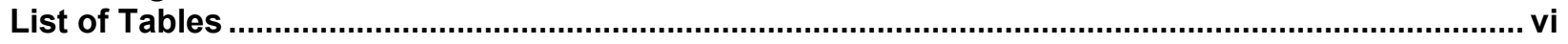

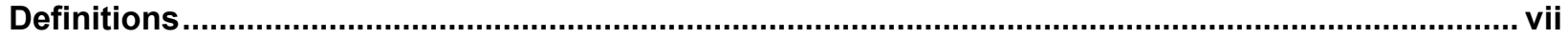

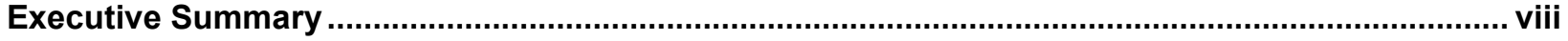

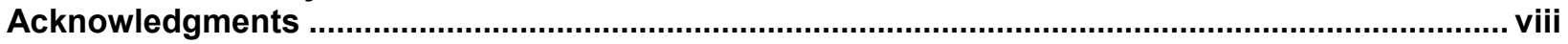

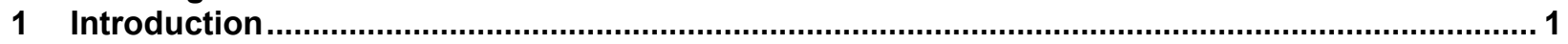

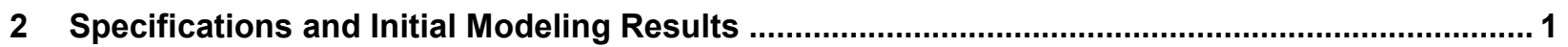

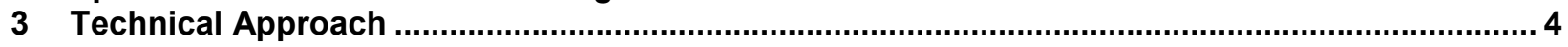

4 Analysis

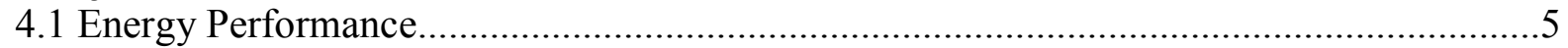

4.2 Space Conditioning System Performance ..............................................................

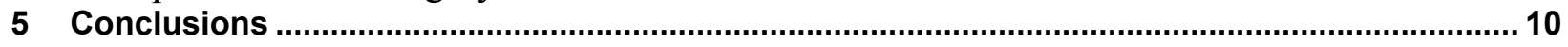

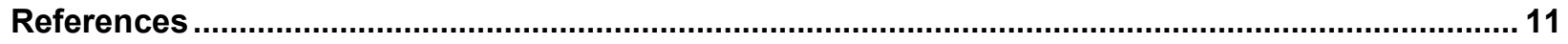




\section{List of Figures}

Figure 1. (Left) Source energy consumption by sub-metered area for the house during the monitoring period from May 2009 to June 2011 in a monthly bar chart, and (right) distribution of a typical year as a pie chart

Figure 2. Graph showing hourly average air temperature at the thermostat and outdoors for the period from Aug.12, 2010 to Aug. 20, 2010

Figure 3. Graph showing hourly average room air temperature difference from the temperature at the thermostat for the period from Aug. 12, 2010 to Aug. 20, 2010.

*Unless otherwise noted, all figures were created by IBACOS.

\section{List of Tables}

Table 1. House Specifications 3

Table 2. Modeled and Measured Source Energy Consumption Compared to BA Benchmark. 7

*Unless otherwise noted, all tables were created by IBACOS. 


\section{Definitions}

$\mathrm{ACH} 50$

BA

CEPHEUS

CFL

CT

DHU

DHW

EPS

ERV

HSPF

MEL

OSB

SEER

SHGC

XPS
Air changes per hour at 50 pascal test pressure

Building America program of the U.S. Department of Energy

Cost Efficient Passive Houses as European Standards

Compact fluorescent lighting

Current transducers

Ductless mini-split heat pump unit

Domestic hot water

Expanded polystyrene

Energy recovery ventilator

Heating seasonal performance factor

Miscellaneous electric load

Oriented strand board

Seasonal energy efficiency ratio

Solar heat gain coefficient

Extruded polystyrene 


\section{Executive Summary}

The Passive House Building Energy Standard is gaining popularity in the United States as a goal for architects and builders to design and construct buildings with very low energy consumption $\left(15 \mathrm{kWh} / \mathrm{m}^{2} \mathrm{yr}\right.$ thermal heating or cooling, $120 \mathrm{kWh} / \mathrm{m}^{2} \mathrm{yr}$ whole-house source energy). Although there is extensive performance data gathered from buildings constructed in Europe, very little data from buildings constructed in the United States exists to assess the detailed energy consumption and occupant comfort characteristics of completed Passive Houses.

The house in this study was designed and built to the Passive House Building Energy Standard incorporating an airtight, super-insulated thermal enclosure and predominantly southern facing windows with calculated overhangs and trellises to provide shading during the summer and maximized solar gain during the winter. A single point mini-split heat pump and electric resistance heaters provide space conditioning, and a balanced energy recovery ventilator (ERV) provides ventilation. The house was extensively instrumented with sub-metering on all major electrical circuits, temperature and humidity measurements in each room, domestic hot water consumption, and recovery efficiency of the ERV. This two-year study intended to document the energy performance of the house in each sub-metered area and compare the performance to modeled predictions and to assess the thermal comfort performance of the single point mini-split heat pump. This report discusses several performance characteristics discovered during the study.

\section{Acknowledgments}

The authors would like to thank the U.S. Department of Energy's Building America program for support to conduct this research; Katrin Klingenberg for designing the house; Mike Kernagis and Tim Gibbs for building the house and ensuring proper sensor installation; and Eric Helton, who played a large role in developing the instrumentation. 


\section{Introduction}

In early 2009, the Ecological Construction Laboratory completed a house that met the Passive House Building Energy Standard as an infill project in an established neighborhood in Urbana, Illinois. Buildings constructed to the Passive House Building Energy Standard are required to achieve very low energy consumption $\left(15 \mathrm{kWh} / \mathrm{m}^{2} \mathrm{yr}\right.$ thermal heating, $15 \mathrm{kWh} / \mathrm{m}^{2} \mathrm{yr}$ thermal cooling, and $120 \mathrm{kWh} / \mathrm{m}^{2} \mathrm{yr}$ whole-house source energy) as modeled using a specialized steadystate spreadsheet-based modeling tool (Feist et al. 2007).

Extensive research conducted in Europe, particularly through the Cost Efficient Passive Houses as European Standards (CEPHEUS) project, shows that modeled predictions compare well with measured performance of built Passive Houses. Typical measurements in these projects categorize energy used as space heating, domestic hot water (DHW), ventilation, and other household uses (Krapmeier and Drössler 2001).

At the time of project planning in late 2007, this house was one of only a handful of houses that met the standard in the United States. Of those houses, very little data was collected. Given the opportunity for an intensive instrumentation program, IBACOS and the Ecological Construction Laboratory collaborated on construction of the house. The collaboration ensured that sufficient measurements were taken to document as many of the unique characteristics of the house as possible and ensured the proper installation of the more than 100 sensors in the house. Although much more was measured, this report focuses on two primary goals of the monitoring effort:

- To document the energy performance of the house in each submetered area and compare to modeled predictions

- To assess the thermal comfort performance of the single point ductless mini-split heat pump unit (DHU).

\section{Specifications and Initial Modeling Results}

To achieve the Passive House Building Energy Standard of $15 \mathrm{kWh} / \mathrm{m}^{2} \mathrm{yr}$ heating thermal energy intensity, the two-story, four-bedroom, 123- $\mathrm{m}^{2}$ (net usable area of 1,324 $\mathrm{ft}^{2}$ ) house incorporates an airtight, super-insulated thermal enclosure and predominantly southern facing windows with calculated overhangs and trellises to provide shading during the summer and to maximize solar gain during the winter. Walls are constructed of 305-mm-thick (12-in.-thick) wooden I-joists used as studs. Use of I-joists in this manner enables construction of a thicker wall assembly while minimizing thermal bridging (Feist et al. 2005a). Cavity bays are filled with fiberglass insulation to a U-value of $0.115 \mathrm{~W} / \mathrm{m}^{2} \mathrm{~K}$ (R-value of $49.2 \mathrm{~h} \mathrm{ft}{ }^{\circ}{ }^{\circ} \mathrm{F} / \mathrm{Btu}$ ). This assembly is sheathed on both sides; the outside is sheathed with fiberboard, and the inside is sheathed with oriented strand board (OSB) glued and mechanically fastened to the I-joist studs to create the primary air barrier for the wall assembly. A $2 \times 3$ dimensional lumber wall is constructed on the interior side of this assembly to accommodate plumbing and electrical wiring without penetrating the air barrier. Cavities of this assembly are filled with cellulose to contribute to a whole wall nominal U-value of $0.0943 \mathrm{~W} / \mathrm{m}^{2} \mathrm{~K}$ (R-value of $60.2 \mathrm{~h} \mathrm{ft}^{2}{ }^{\circ} \mathrm{F} / \mathrm{Btu}$ ) (Klingenberg 2007).

Ceiling insulation is loose-fill cellulose applied to the attic floor to a U-value of $0.0652 \mathrm{~W} / \mathrm{m}^{2} \mathrm{~K}$ (R-value of $87 \mathrm{~h} \mathrm{ft}^{2}{ }^{\circ} \mathrm{F} / \mathrm{Btu}$ ). Continuous polyethylene sheets attached to the bottom chord of the 
trusses with joints taped provide the air barrier; electrical wiring is routed to the interior of the air barrier in a cavity formed by $2 \times 4$ dimensional lumber attached to the bottom chord of the trusses.

The above measures and meticulous attention to detail with air sealing resulted in the house having a blower door tested air leakage rate of 0.45 air changes per hour at 50 Pascal test pressure (0.45 ACH50).

Windows in the house were among the best performing windows available on the North American market at the time of construction. Consisting of triple glazing with low-e coating, inert gas fill, warm-edge spacers, and insulated fiberglass frames, they achieve U-values of $0.91 \mathrm{~W} / \mathrm{m}^{2} \mathrm{~K}\left(0.16 \mathrm{Btu} / \mathrm{h} \mathrm{ft}^{2}{ }^{\circ} \mathrm{F}\right)$ for the southern orientation and $0.85 \mathrm{~W} / \mathrm{m}^{2} \mathrm{~K}\left(0.15 \mathrm{Btu} / \mathrm{h} \mathrm{ft}^{2}{ }^{\circ} \mathrm{F}\right)$ for the other orientations. Glazing with higher solar heat gain coefficients (SHGCs) was installed for southern orientations to take advantage of incident low angle sunlight during the winter to reduce the heating energy required for the house. A lower SHGC was installed for the east and west orientations to reduce the cooling load of the house during the summer. Additionally, the overhang above the second floor southern facade windows was dimensioned to ensure that it fully shades those windows during the summer. Southern windows on the first floor were intended to be shaded via deciduous plants growing on a trellis; however, these had not yet grown in during the course of the monitoring period.

Primary heating is provided by $500-\mathrm{W}(1,706-\mathrm{Btu} / \mathrm{h})$ electric resistance baseboards located in each bedroom, the living room, and the dining area. These are controlled by a central thermostat with individual unit restriction control. Primary cooling is provided by a DHU of approximately $2,600-\mathrm{W}(9,000-\mathrm{Btu} / \mathrm{h})$ capacity with efficiency ratings of 20 seasonal energy efficiency ratio (SEER), 13.85 energy efficiency ratio, and 10 heating seasonal performance factor (HSPF) (Samsung 2006). The indoor unit of the DHU is located in the stairwell of the house between the first and second floors. Its location measures approximately $3.3 \mathrm{~m}(10 \mathrm{ft})$ vertically above the first floor. Although installed primarily for the purpose of cooling the house, the unit also has the ability to heat. An energy recovery ventilator (ERV) provides continuous balanced ventilation. Fresh air is ducted to each bedroom and the living room, while stale air is exhausted from the bathrooms, kitchen, and laundry closet.

Full specifications can be seen in Table 1. The house was occupied by two adults and one child throughout the monitoring period from May 2009 through June 2011. 
Table 1. House Specifications

\begin{tabular}{|c|c|}
\hline Building envelope & \\
\hline Geometry & $123 \mathrm{~m}^{2}$ (net usable area, $1,324 \mathrm{ft}^{2}$ ), 2 stories, 4 bedrooms, 2 bathrooms \\
\hline Ceiling & 20 in. of blown cellulose, R-87 total \\
\hline Walls & $\begin{array}{r}12 \text { in. TJI framing } 24 \text { in. on center (R-49.2) }+2 \times 3 \text { framing } 24 \text { in. on } \\
\text { center }(\mathrm{R}-11) \text {, R-60 total }\end{array}$ \\
\hline Foundation & $\begin{array}{r}16 \text { in. of low-density expanded polystyrene (EPS) under slab (R-56) } \\
4 \text { in. of high-density extruded polystyrene (XPS) under thickened } \\
\text { slab edge (R-20) } \\
2 \text { in. of low-density XPS around perimeter (R-10) }\end{array}$ \\
\hline Windows & $\begin{array}{l}\text { South windows } U=0.16, \text { SHGC }=0.61 \\
\text { Other windows } U=0.15, \text { SHGC }=0.51\end{array}$ \\
\hline Infiltration & $0.45 \mathrm{ACH} 50$ \\
\hline Mechanical systems & \\
\hline Heating & $\begin{array}{r}\text { Mini-split heat pump, } 10.0 \text { HSPF with } 6 \times 500-W \begin{array}{r}\text { baseboard electric } \\
\text { resistance backup }\end{array}\end{array}$ \\
\hline Cooling & Mini-split air conditioner, 20 SEER \\
\hline DHW & Electric tankless, $\mathrm{EF}=0.98$ \\
\hline Ducts & Ventilation air only - in conditioned space \\
\hline Leakage & None to outside $(0.5 \%)$ \\
\hline Ventilation & 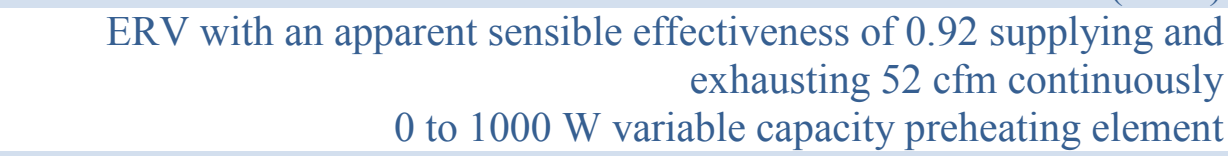 \\
\hline Appliances & $\begin{array}{l}\text { Major appliances used in the houses were electric and ENERGY } \\
\text { STAR } 囚 \text { rated (dishwasher, refrigerator, and high efficiency washer with } \\
\text { condensing dryer) }\end{array}$ \\
\hline Lighting & $0 \%$ energy efficient fixtures, $81 \%$ screw-in CFL bulbs \\
\hline
\end{tabular}

As part of the inclusion of the Urbana Passive House in the U.S. Department of Energy's Building America (BA) program, the source energy consumption was calculated using EnergyGauge (Version 2.8). This calculation is compared in Table 2 later in this report to the performance of the BA Benchmark reference house (2007 version), the construction of which is based on mid-1990s energy codes (Hendron 2007). Typical thermal enclosure specifications for the BA Benchmark reference house include a wall assembly nominal U-value of $0.437 \mathrm{~W} / \mathrm{m}^{2} \mathrm{~K}$ (R-value of $13 \mathrm{~h} \mathrm{ft}^{2}{ }^{\circ} \mathrm{F} / \mathrm{Btu}$ ), ceiling U-value of $0.149 \mathrm{~W} / \mathrm{m}^{2} \mathrm{~K}$ (R-value of $38 \mathrm{~h} \mathrm{ft}^{2}{ }^{\circ} \mathrm{F} / \mathrm{Btu}$ ), and house depressurization test results of approximately $5 \mathrm{ACH} 50$. As documented by IBACOS (2008 and 2010), initial modeling results predicted the Urbana Passive House to achieve 48\% source energy savings compared to the BA Benchmark reference house. 


\section{Technical Approach}

This two-year study was intended to document and compare to modeled predictions the energy performance of the house in each sub-metered area-heating, cooling, domestic hot water, lighting, major appliances, and miscellaneous electric loads (MELs) - and to assess the ability of the DHU to provide uniform room air temperatures throughout the house.

To document the electrical performance of each of the areas, coordination with the electrician occurred prior to construction to ensure that each of the sub-metered areas, especially lighting and outlets, were kept on separate circuits. For circuits containing non-resistive loads, pulse output Watt-hour meters (4 Hz full-scale frequency) were installed with appropriately sized current transducers (CTs) rated at no more than a factor of 2 greater than the anticipated maximum load. For circuits with only resistive loads (the electric resistance heating elements), voltage output CTs were installed. Watt-hours were calculated using the following equation:

$$
W-h=A_{\text {measured }} \times 244
$$

where

$A_{\text {measured }}$ is the measured amperage from the CT

244 is the typical line voltage

Typically, the electrical measurements are taken in the main circuit panel; however, due to the large number of electrical measurements being taken, all electrical circuits were first routed through a 24 -in. $\times 13$-in. $\times 8$-in. electrical box located adjacent to the main electrical panel to facilitate the sensor installation.

To determine the DHU's ability to provide uniform air temperatures throughout the house, temperature measurements were taken in each of the three bedrooms, the bathroom, and the landing on the second floor, along with the living room, dining room, bedroom, bathroom, and thermostat location on the first floor. Care was taken to locate the temperature measurements along interior partition walls that would not be hit directly by incident solar radiation entering through windows. Additionally, a thermocouple was placed in the airspace directly below the wall-mounted indoor portion of the DHU to measure any localized cooling occurring near the unit. To determine if the ERV had a significant impact in circulating cooled air through the house, the temperature of the fresh air that the ERV supplied to the rooms was also measured. Type $\mathrm{T}$ thermocouples were used for all indoor temperature measurements. Reference temperature was taken at the data logger using a thermistor. Outdoor temperature and relative humidity also were measured.

All sensors were connected to a central data logger using low-voltage shielded wire. Sensors were sampled every 10 seconds with $60 \mathrm{~Hz}$ noise cancelling integration used to mitigate any noise due to electrical power lines. The data were averaged on both a minute basis and an hourly basis. A cellular data modem was used to allow daily remote collection. 
Source energy consumption is calculated from measured site electricity consumption via the following equation:

$$
E_{\text {Source }}=E_{\text {Site }} \times M_{e},
$$

where

$E_{\text {Site }}$ is the measured electrical energy consumption

$\mathrm{M}_{\mathrm{e}}$ is the site to source conversion factor equaling 3.365 (Hendron and Engebrecht 2010)

The estimated heating and cooling thermal energy are calculated using the following equations, respectively:

$$
\begin{aligned}
& E_{\text {heating }}=E_{\text {Elec Res }}+\left(E_{D H U} \times 1,000 \times \text { Eff DHUheating }^{\circ}, 3,412\right) \\
& E_{\text {cooling }}=E_{D H U} \times 1,000 \times E f f_{\text {DHUcooling }} \div 3,412,
\end{aligned}
$$

where

$E_{\text {ElecRes }}$ is the measured site electricity consumption of the electric resistance baseboard heat $(\mathrm{kWh})$

$E_{D H U}$ is the measured site electricity consumption (kWh) of the DHU

Eff $_{\text {DHUheating }}$ is the rated HSPF (Btu output/Wh input) of the DHU equaling 10

Eff $_{\text {DHUcooling }}$ is the rated SEER (Btu output/Wh input) of the DHU equaling 20

1,000 is a unit conversion factor (Wh per $\mathrm{kWh}$ )

3,412 is a unit conversion factor (Btu per $\mathrm{kWh}$ )

\section{Analysis}

\subsection{Energy Performance}

Data from two years of monitoring show that when space conditioning loads are reduced drastically, DHW and lighting, appliances, and MELs dominate house electric consumption. Figure 1 shows that, on an annual basis, DHW constitutes approximately a third of the total house energy consumption. In this house, DHW is provided by an electric resistance tankless water heater, a relatively inefficient method from a source energy standpoint. More efficient options such as a heat pump water heater or fuel fired tankless water heater offer energy reduction potential in the area of DHW. Lighting, appliances, and MELs constitute another third of the total house energy consumption, with the remaining third consumed by space conditioning and ventilation Although the DHU is used primarily during summer cooling months, while the ERV operates continuously year round, their respective total energy consumption values are actually closely equivalent (see Figure 1). Heating energy, provided primarily by electric resistance in the winter, equaled energy required for MELs, and annual cooling energy was slightly less than the ERV fan energy. 


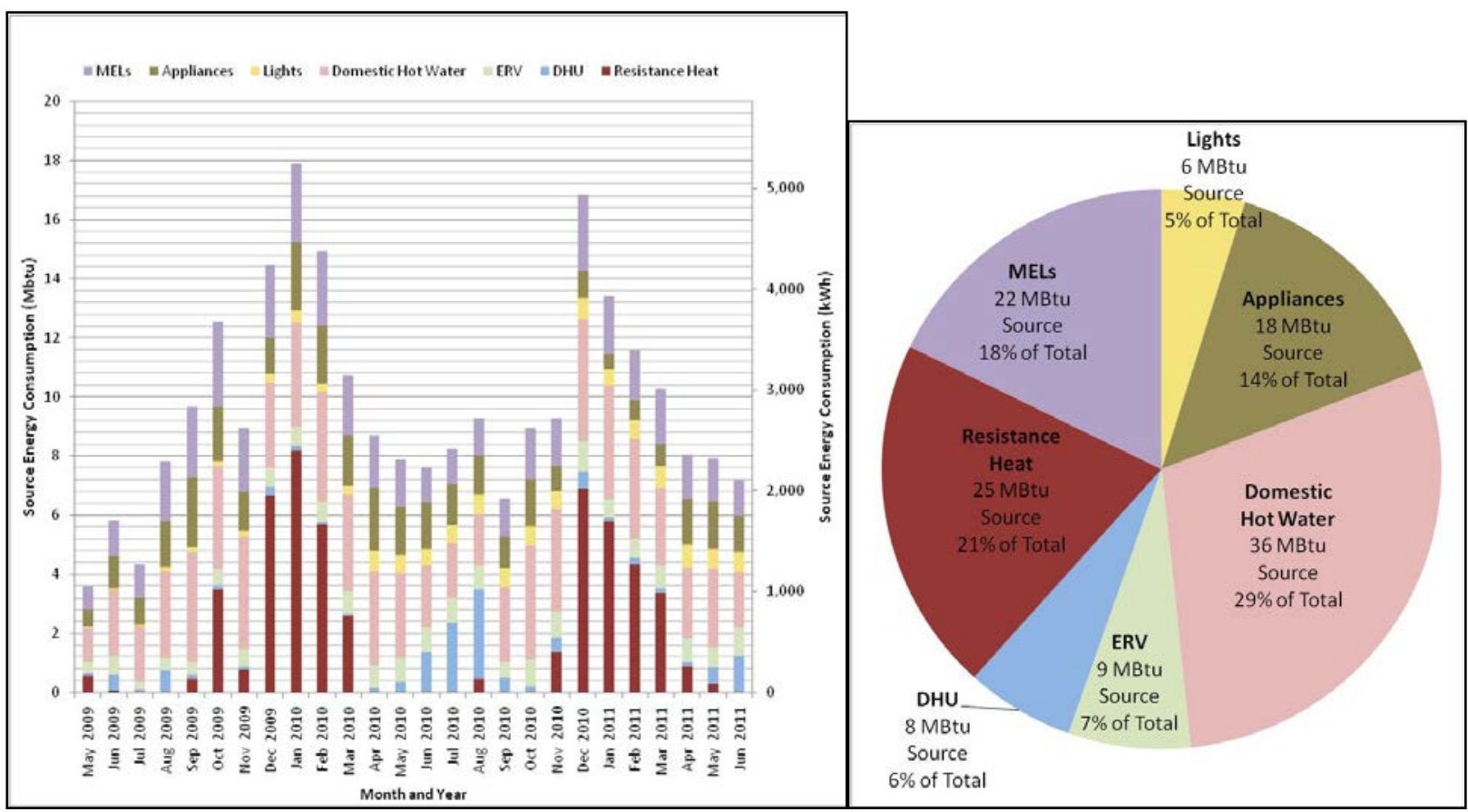

Figure 1. (Left) Source energy consumption by sub-metered area for the house during the monitoring period from May 2009 to June 2011 in a monthly bar chart, and (right) distribution of a typical year as a pie chart

Modeled source energy consumption by subcategory, calculated using EnergyGauge (Version 2.8), is compared to measured source energy consumption in Table 2. As shown in the table, the measured performance is slightly better than the modeled performance in all areas; in particular, measured heating energy consumption is $33 \%$ less than predicted, and measured cooling energy consumption is $20 \%$ less than predicted. These differences can be accounted for by many factors, including the degree of precision and assumptions in the model such as occupancy, indoor operating temperatures, and outdoor weather conditions. Measured data show that interior temperatures were kept close to modeled set point values on average $\left(21.7^{\circ} \mathrm{C}\left(71^{\circ} \mathrm{F}\right)\right.$ heating and $24.4^{\circ} \mathrm{C}\left(76^{\circ} \mathrm{F}\right)$ cooling) throughout the course of the monitoring period. The only areas of deviation occurred between April and June 2010, where indoor temperatures were maintained at $22.8^{\circ} \mathrm{C}\left(73^{\circ} \mathrm{F}\right)$ for cooling, which is cooler than modeled and increased measured energy consumption compared to modeled energy consumption.

The Passive House Building Energy Standard requires houses to use no more than $15 \mathrm{kWh} / \mathrm{m}^{2}$ $\left(4,754 \mathrm{Btu} / \mathrm{ft}^{2}\right)$ heating thermal energy and $15 \mathrm{kWh} / \mathrm{m}^{2}\left(4,754 \mathrm{Btu} / \mathrm{ft}^{2}\right)$ cooling thermal energy throughout the course of one year when modeled (Feist et al. 2007). Data collected for space heating and cooling over the two-year period show the house had a typical annual heating thermal energy intensity of $18.7 \mathrm{kWh} / \mathrm{m}^{2}\left(5,930 \mathrm{Btu} / \mathrm{ft}^{2}\right)$, approximately $25 \%$ greater than the requirement. However, the absolute magnitude is important to consider in this case as the annual difference of $3.7 \mathrm{kWh} / \mathrm{m}^{2}\left(1,173 \mathrm{Btu} / \mathrm{ft}^{2}\right)$ is approximately equivalent to the heat output by one person at rest in the house 12 hours per day. One potential reason for the slightly higher consumption is that during the winter, interior temperatures were maintained at $21.7^{\circ} \mathrm{C}\left(71^{\circ} \mathrm{F}\right)$ degrees, which was higher than the modeled assumption of $20^{\circ} \mathrm{C}\left(68^{\circ} \mathrm{F}\right)$. 
Based on measured electricity consumption of the DHU, the annual cooling thermal energy intensity is calculated to be $33.3 \mathrm{kWh} / \mathrm{m}^{2}\left(10,600 \mathrm{Btu} / \mathrm{ft}^{2}\right)$, assuming that the DHU performed at its rated SEER. While the measured heating energy closely matches the requirement, the cooling thermal energy required appears to be $122 \%$ greater than the requirement. However, the measured value is not directly comparable because part of this value is due to latent loads that are not accounted for in the $15 \mathrm{kWh} / \mathrm{m}^{2}$ yr sensible cooling thermal energy requirement. Future studies assessing the thermal characteristics of Passive Houses should incorporate more detailed methods of measuring sensible and latent energy output of DHUs. Publicly available procedures for this measurement have been developed by the National Renewable Energy Laboratory (Christensen et al. 2011).

Table 2. Modeled and Measured Source Energy Consumption Compared to BA Benchmark

\begin{tabular}{|c|c|c|c|c|c|}
\hline \multirow[b]{2}{*}{ Description } & \multicolumn{3}{|c|}{ Annual Source Energy Consumption } & \multicolumn{2}{|c|}{$\begin{array}{l}\text { Annual Source Energy } \\
\text { Percentage Savings of } \\
\text { Urbana House versus } \\
\text { Benchmark }\end{array}$} \\
\hline & $\begin{array}{l}2007 \text { BA } \\
\text { Benchmark }\end{array}$ & $\begin{array}{l}\text { Urbana } \\
\text { House } \\
\text { Modeled } \\
\end{array}$ & $\begin{array}{l}\text { Urbana } \\
\text { House } \\
\text { Monitored } \\
\end{array}$ & Modeled & Measured \\
\hline End Use & $\begin{array}{l}\text { kWh/yr } \\
\text { (MBtu/yr) }\end{array}$ & $\begin{array}{l}\text { kWh/yr } \\
\text { (MBtu/yr) }\end{array}$ & $\begin{array}{l}\text { kWh/yr } \\
\text { (MBtu/yr) }\end{array}$ & $\%$ & $\%$ \\
\hline $\begin{array}{l}\text { Space } \\
\text { Heating }\end{array}$ & $12,600(145)$ & $3,100 \quad(36)$ & $2,100 \quad(24)$ & $75 \%$ & $83 \%$ \\
\hline $\begin{array}{l}\text { Space } \\
\text { Cooling }\end{array}$ & $2,000 \quad(23)$ & $1,000 \quad(12)$ & 800 & $49 \%$ & $61 \%$ \\
\hline DHW & $4,500 \quad(52)$ & $3,100 \quad(36)$ & $3,000 \quad(35)$ & $31 \%$ & $33 \%$ \\
\hline Lighting & $1,500 \quad(17)$ & $800 \quad(9)$ & 500 & $48 \%$ & $65 \%$ \\
\hline Appliances & $2,500 \quad(29)$ & $2,400 \quad(28)$ & $1,700 \quad$ (19) & $5 \%$ & $34 \%$ \\
\hline MELs & $3,300 \quad(38)$ & $3,300 \quad(38)$ & $2,700 \quad(31)$ & $0 \%$ & $18 \%$ \\
\hline Total & $26,600(305)$ & $13,800(158)$ & $10,800(124)$ & $48 \%$ & $59 \%$ \\
\hline
\end{tabular}

Note: The subtotals are rounded to the nearest MBtu or hundred $\mathrm{kWh}$ for display purposes. The total for each column is the sum of the raw, non-rounded subcategory values. The total is then rounded to the nearest MBtu or hundred $\mathrm{kWh}$ for display purposes.

\subsection{Space Conditioning System Performance}

In addition to comparing measured and modeled performance, a goal of this study was to assess the thermal comfort and energy performance of the DHU. The decision to use a DHU was made, in part, out of necessity due to the lack of traditional ducted forced-air systems available in the necessary capacity. Although controversial when installed, its use was based, in part, on the hypothesis that in a Passive House, heating and cooling energy will be distributed sufficiently throughout the house via convective currents through open doors or transfer grilles, buoyancy, and conduction through interior partition walls. This hypothesis is based on research performed by Feist et al. (2005b), where computational fluid dynamics models of dwellings meeting the Passive House Building Energy Standard indicated that, at $1^{\circ} \mathrm{C}\left(1.8^{\circ} \mathrm{F}\right)$ delta $\mathrm{T}$, it is possible to have conductive transfer of 1 to $2 \mathrm{~W} / \mathrm{m}^{2}\left(0.3\right.$ to $\left.0.6 \mathrm{Btu} / \mathrm{hr}-\mathrm{ft}^{2}\right)$ of wall area and convective transfer of approximately 100 to $200 \mathrm{~W}$ (300 to $600 \mathrm{Btu} / \mathrm{hr}$ ) per open interior door. 
Results obtained during 2010 support this hypothesis and indicate that the system is effective at providing fairly uniform temperatures throughout the house while actively cooling during the summer months. Even during peak cooling conditions, all rooms were generally within $1.7^{\circ} \mathrm{C}$ $\left(3^{\circ} \mathrm{F}\right)$ of the temperature at the thermostat. In fact, during this period, the system was able to cool the house below the set point of the electric resistance heat, causing a brief period of simultaneous heating and cooling (Figure 2 and Figure 3). During this time, the DHU was able to maintain its set cooling temperature despite full operation of the electric resistance heat.

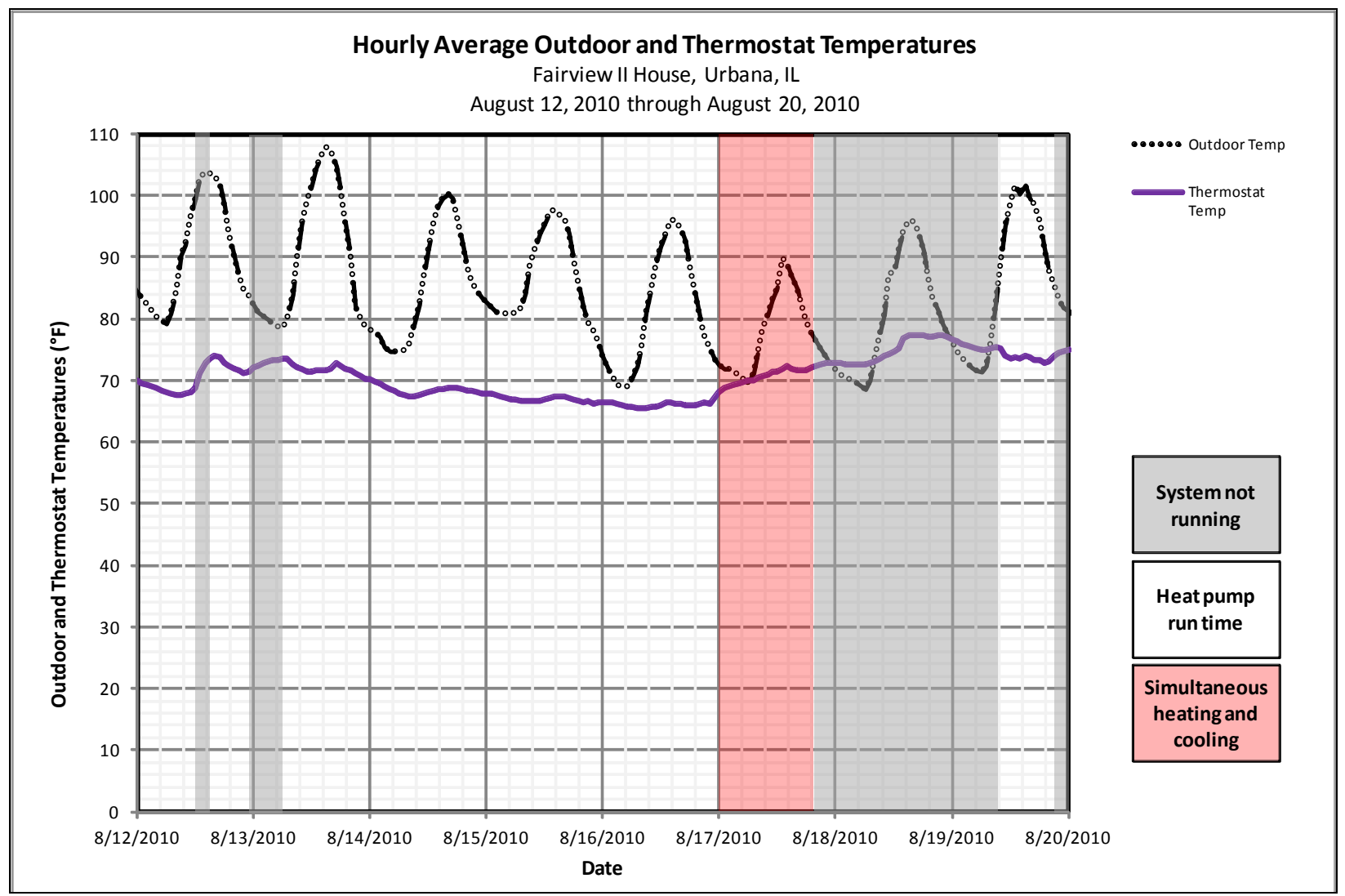

Figure 2. Graph showing hourly average air temperature at the thermostat and outdoors for the period from Aug.12, 2010 to Aug. 20, 2010 


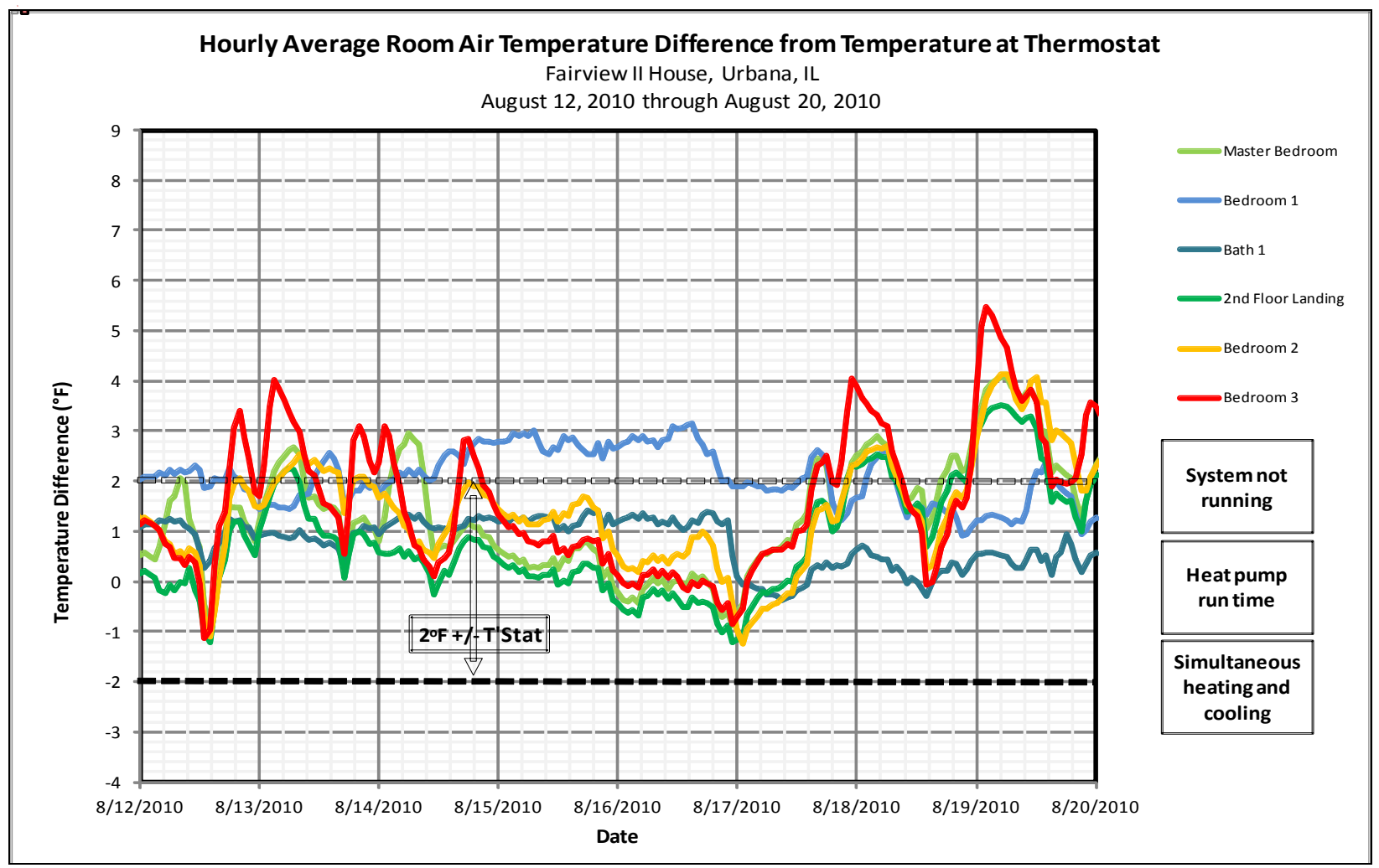

Figure 3. Graph showing hourly average room air temperature difference from the temperature at the thermostat for the period from Aug. 12, 2010 to Aug. 20, 2010

Although it is impressive that the cooling system maintained temperature, the results bring to light the need for controls integration for DHUs when used in conjunction with other heating systems. During the winter, lack of controls integration was a factor in the lack of operation of the heat pump.

Although true in both seasons, this problem became most evident in the winter. In traditional forced-air systems, the temperature sensors are located remotely from the unit at a user interface; however, the temperature sensor on the DHU is located directly on the DHU itself. Because the DHU is located in a relatively confined stairwell space, it tends to heat the stairwell quickly and turn itself off.

Furthermore, the location of the DHU above the plane of the first floor ceiling prevents sufficient heating energy from reaching the downstairs living space, even when the DHU runs for a 10minute duration. Because all baseboards are controlled via a centrally located thermostat in the first floor living space, this lack of sufficient heating energy to the first floor causes the thermostat for the baseboard heat to trigger the operation of the electric resistance heat. Because of this system behavior, the occupant chose to minimize operation of the heat pump during the winter. The electric resistance heat was able to maintain uniform room temperatures within $1{ }^{\circ} \mathrm{C}$ $\left(1.8^{\circ} \mathrm{F}\right)$ of the temperature at the thermostat location. 
It also was initially anticipated that the low volume of tempered air delivered continuously by the ERV to the living space and bedrooms would assist in distribution of cool air throughout the house. However, minute-by-minute data reveal that the ERV did not actively distribute cooled air to individual rooms but instead supplied ventilation air that was typically between $1^{\circ} \mathrm{C}$ and $3^{\circ} \mathrm{C}\left(2^{\circ} \mathrm{F}\right.$ and $\left.6^{\circ} \mathrm{F}\right)$ above indoor ambient temperatures and that slightly increased the cooling load in each room. The influence of the continuously supplied ventilation air in preventing stagnation and stratification in individual rooms and throughout the house was not measured.

\section{Conclusions}

The results of approximately two years of data collection from May 2009 to June 2011 in a Passive House in Urbana, Illinois, show that the house performs better than anticipated with respect to source energy consumption compared to typical models used in the BA program. It performed closely to the predicted values required to meet the Passive House Building Energy Standard in heating. Issues related to measuring thermal energy provided by DHUs prevent a true comparison to the Passive House Building Energy Standard in cooling. The DHU was effective in cooling the house to uniform interior temperatures throughout the summer; however, its placement within the house proved detrimental to its ability to heat the house in the winter. When installing a DHU in conjunction with any other heating or cooling system, integration of controls is essential to prevent erratic behavior of the devices. The effectiveness of the DHU at cooling the house raises the question as to the unmeasured elements that may have contributed to its success, such as the contribution of the ventilation system to preventing room air stagnation. Regardless, it appears to be a reasonable strategy for houses of this type, with potential for more widespread application. The minimum climate-specific enclosure requirements for such a system to be effective should be explored in future research. 


\section{References}

Christensen, D. et al. (2011). Field Monitoring Protocol: Mini-Split Heat Pumps. Golden, CO: National Renewable Energy Laboratory, Accessed March 2011.

http://www.nrel.gov/docs/fy11osti/49881.pdf.

Feist, W., et al. (2005a). Protokollband Nr. 16 -Arbeitskreis Konstengünstige Passivhäuser Phase II. Darmstadt: Passive House Institute, pp. 83-89.

Feist, W. et al. (2005b). "Re-inventing Air Heating: Convenient and Comfortable within the Frame of the Passive House Concept." Energy and Buildings, 37, pp. 1186-1203.

Feist, W., et al. (2007). Passive House Planning Package. Darmstadt: Passive House Institute.

Hendron, R. (2007). Building America Research Benchmark Definition, Updated December 15, 2006. NREL/TP-550-40968. Golden, CO: National Renewable Energy Laboratory, January 2007.

Hendron, R. and Engebrecht, C. (2010). Building America Research Benchmark Definition, Updated December 2009. NREL/TP-550-47246. Golden, CO: National Renewable Energy Laboratory, January 2010.

IBACOS (2008). Building America Program Annual Report Budget Period 1. DE-FC2608NT02231. Pittsburgh, PA: IBACOS. December 2008.

IBACOS (2010). Building America Program Annual Report Budget Period 2. DE-FC2608NT02231. Pittsburgh, PA: IBACOS. February 2010.

Klingenberg, K. (2007). Personal communication. August 2007.

Krapmeier, H. and E. Drössler. (2001). CEPHEUS - Living Comfort without Heating. New York, NY: Springer-Verlag.

Samsung. (2006). Split Type Air Conditioner AQB09JJWC/AQB12JJWC Service Manual. China: Samsung Electronics Co. 


\section{U.S. DEPARTMENT OF Energy Efficiency \& ENERCY Renewable Energy}

